\title{
Physiological changes associated with Okra mosaic virus infection in field grown okra plants
}

\author{
Samuel Amiteye 1,2, Andrew Sarkodie Appiah ${ }^{1 *}$, Frederick Boateng², Jacob Teye Kutufam¹, \\ Harry Mensah Amoatey ${ }^{2}$ \\ ${ }^{1}$ Biotechnology Centre, Biotechnology and Nuclear Agricultural Research Institute (BNARI), Accra, Ghana \\ ${ }^{2}$ Department of Nuclear Agriculture and Radiation Processing, School of Nuclear and Allied Sciences, College of Basic and \\ Applied Sciences, University of Ghana, Accra, Ghana
}

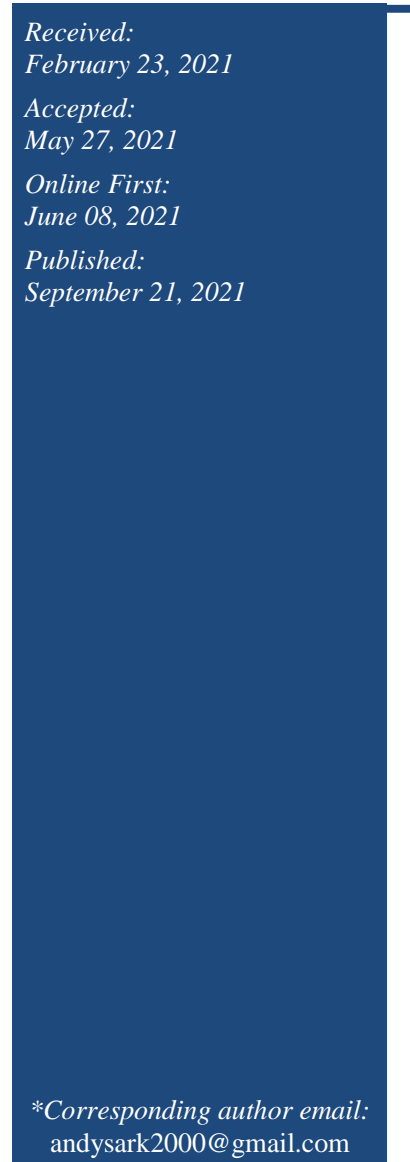

\begin{abstract}
As a prerequisite for the breeding of virus-resistant okra cultivars, the effect of Okra mosaic virus infection on physiological performance of ten okra cultivars were assessed under field conditions within the coastal savannah agro-ecological zone of Ghana. All cultivars succumbed to the disease and expressed varying degrees of symptoms. The results showed that plant height at initial and 50\% flowering were significantly reduced with cultivar Clemson spineless showing the highest reduction of $38 \%$ and $35 \%$ respectively. Plant height at $50 \%$ podding was also reduced in all cultivars with the highest reduction (40\%) occurring in cultivar Clemson spineless. Virus-infected plants of cultivars Kwabenya 1, Labadi dwarf and Asutem took on the average 43 days to attain 50\% flowering compared to 25 days in healthy or control plants. Diseased plants had significantly $(\mathrm{P}<0.05)$ delayed, taking on the average 47 days after planting to attain 50\% podding compared to the control plants with an average of 35 days. Infected plants of cultivars Kwabenya 1 and Labadi dwarf took the highest number of 51 days to attain 50\% podding. Pod length and width were also reduced in all cultivars but were highest in cultivars Lucky $19 \mathrm{~F} 1$ and Clemson spineless at $52.19 \%$ and $46.25 \%$ respectively. Based on this assessment, cultivars Adom and Asutem which were less affected in terms of disease severity and fruit yield reduction could be exploited in future breeding programmes.
\end{abstract}

Keywords: Okra, Plant growth, Okra mosaic virus, Virus resistant, Symptoms

\section{How to cite this:}

Amiteye S, Appiah AS, Boateng F, Kutufam JT and Amoatey HM, 2021. Physiological changes associated with Okra mosaic virus infection in field grown okra plants. Asian J. Agric. Biol. 2021(4): 202102097. DOI: https://doi.org/10.35495/ajab.2021.02.097

This is an Open Access article distributed under the terms of the Creative Commons Attribution 3.0 License. (https://creativecommons.org/licenses/by/3.0), which permits unrestricted use, distribution, and reproduction in any medium, provided the original work is properly cited.

\section{Introduction}

Okra (Abelmoschus esculentus L. Moench) is grown for its immature fruits and fresh tender leaves. These plant parts serve as food and an important source of raw materials for some pharmaceutical and other industrial applications due to the high phytochemical and nutritional content (Adetuyi et al., 2011). Okra is a robust crop, hence is able to survive harsh conditions where most other crops fail (Oppong-Sekyere et al, 2012). This unique agronomic quality coupled with its rich nutritional qualities make it a very popular crop for resource-poor small-holder farmers in rural areas across tropical Africa. 
Notwithstanding the importance of okra as a domestic and export crop, its production is constrained by severe crop damage and low yields due to viral diseases (Chen et al., 2019; Asare-Bediako et al., 2014; Savary et al., 2012), hence the full food, medicinal and economic potentials of the crop are not realized. The most important viruses of okra include Okra Yellow Vein Mosaic Virus (OYVMV), Okra Mosaic Virus (OkMV) and Okra Leaf Curl Virus (OLCV). These viruses are widespread in tropical and subtropical regions across the world. OkMV has been reported as widespread in Ghana, resulting in significant yield losses (Appiah et al., 2020). The virus is a member of Tymovirus group, characterised by a single stranded DNA (ssDNA) gonome and spread by the flea beetle Podagrica spp (Asare-Bediako et al., 2014).

These important okra viruses infect okra plants either singly or mixed. According to Hull (2002), mixed viral infections could be either antagonistic or synergistic. Antagonism normally arises when co-infecting viruses are related resulting in cross protection (Aguero et al., 2018) or interference (Kumar et al., 2016). Synergism also arises when co-infecting viruses are not related, resulting in more severe disease symptoms than those caused by single infections (Cho et al., 2000). Studies done by Ndunguru and Rajabu (2004), revealed that okra exhibits a variety of symptoms which usually ranged from mild to severe, caused by either single or mixed virus infections. In mild situations, okra show symptoms such as veinal mottling, vein banding and leaf mosaic. In severe cases, however, infected plants show small and twisted leaves, downward curling of mature leaves, deformed fruits and stunted growth.

A large variety of okra cultivars exist in Ghana and are predominantly cultivated across the major okragrowing regions of the country (Ahiakpa et al., 2017). These cultivars include exotic types sold by commercial seed companies with several trade names. Unfortunately, almost all known cultivars of okra currently cultivated in Ghana, both local and exotic are highly susceptible to the major viruses and many species of insect pests (Oppong-Sekyere et al, 2012; Prakasha et al., 2010; Petlamul et al., 2009). The implication of this is that production levels of okra have been generally very low. Although, some works have already been done in Ghana, most of these studies have focused on viral disease epidemiology, little is known about the effects of viral diseases on growth and performance of different okra cultivars.

There is, therefore, the need to evaluate the effects of OkMV on cultivated okra cultivars present in Ghana in order to be able to recommend the best cultivars for farmers in the short term and in the long term, those to be incorporated into breeding programmes to expand the genetic variation of the crop. The present study, therefore, sought to evaluate the effects of OkMV infection on ten okra cultivars in order to identify better performing cultivars.

\section{Material and Methods}

\section{The study area}

The research was conducted on the research fields of the Biotechnology and Nuclear Agriculture Research Institute (BNARI) of the Ghana Atomic Energy Commission (GAEC). The study area is located at Kwabenya, Accra on latitude $5^{\circ} 40^{\prime} \mathrm{N}$, longitude $0^{\circ} 13^{\prime}$ $\mathrm{W}$ with Ochrosol (Ferric Acrisol) soil type, derived from quartzite Schist. The site is well drained and has an elevation of $76 \mathrm{~m}$ above sea level within the coastal savannah agro-ecological zone (Dickson and Benneh, 2004). The maximum and minimum average temperatures for the period of study were 30.7 and 26.0 ${ }^{\circ} \mathrm{C}$ respectively with average annual rainfall of 220 $\mathrm{mm}$. The highest and lowest relative humidity were 75 and 60\% respectively (Dickson and Benneh, 2004).

\section{Planting materials and field design}

Planting materials used comprised five exotic okra cultivars namely; Lucky 19F1 (LF1), F1 Kirene (FIK), F1 Sahari (F1S), Kirikou F1 (KF1) and Clemson Spineless (CS) obtained from Technisem, Accra and five local okra cultivars comprising Asutem (AS), Togo (TG), Labadi dwarf (LD), Kwabenya 1 (K1) and Adom (AD) obtained from the local markets and okra farmers' fields.

After land preparation and field demarcation, the okra seeds were directly sown to a depth of $2 \mathrm{~cm}$ at a spacing of $0.50 \mathrm{~m} \times 0.60 \mathrm{~m}$ between and within rows in a Randomized Complete Block Design (RCBD) with four replications. Each replicate measured $35 \mathrm{~m} \mathrm{x} 7 \mathrm{~m}$ and were separated by $2 \mathrm{~m}$ from each other. Each block consisted of 10 subplots with each subplot measuring $3 \mathrm{~m} \times 3 \mathrm{~m}$ and spaced $1 \mathrm{~m}$ from one another. Four seeds per hill were sown and later thinned to one seedling after emergence. Cultural management practices such as weed control and watering were done as and when required.

\section{Data collection}

Ten plants were randomly selected from the middle rows of each plot per cultivar and tagged. The ten 
selected plants consisted of five healthy or control plants and five infected plants. Symptom severity was scored on the diseased plants following a five-point scale ( 0 to 4$)$ where; $\mathbf{0}=$ No symptom; $\mathbf{1}=$ Very mild symptoms, initial vein clearing, initial leaf yellowing, mild curling and blistering; $\mathbf{2}=$ Leaf completely yellow and inter-veinal regions remain green or yellow and blistering; $\mathbf{3}$ = Severe curling, yellowing, stunting and blistering; and $\mathbf{4}=$ Severe yellowing, curling, blistering and deformed pods (All leaves of the plants affected). Data was collected on quantitative traits with respect to reproductive and pod characters. The reproductive characters comprised Days to $50 \%$ flowering, Days to $50 \%$ podding, Plant height at initial flowering stage, Plant height at 50\% flowering stage, and Plant height at $50 \%$ podding stage. Days to $50 \%$ flowering and Days to $50 \%$ podding were determined by counting the days after plant emergence. On the other hand, plant height at initial flowering stage, plant height at 50\% flowering stage, and plant height at $50 \%$ podding stage were measured using tape measure and recorded in centimetres $(\mathrm{cm})$. Chlorophyll contents of the cultivars were measured using hand-held SPAD meter. The pod characters that were recorded included pod length, pod width and fresh fruit weight. The pod length and width were taken with a tape measure and the mean for five plants recorded. Fresh fruit weight was measured with a spring balance and the mean recorded in kilogram $(\mathrm{kg})$.

\section{Statistical analysis}

Genstat Statistical Software Package (12 ${ }^{\text {th }}$ edition), and Microsoft Excel Software (2010 edition) were used for the data analyses and a p-value of 0.05 or less was considered as statistically significant. The data collected on diseased and healthy plants were subjected to Analysis of variance (ANOVA) and the Tukey's pairwise comparison test was used to determine the differences among the means.

\section{Results}

\section{Viral disease symptom severity}

Disease symptoms were found mostly in the young leaves and included leaf yellowing, leaf malformation, vein clearing, mosaic, leaf blistering, upward cupping of leaves and stunting (Fig. 1).

Generally, symptom severity increased steadily from week 3 to week 13 for all cultivars (Fig. 2). Cultivar Kwabenya 1 and Lucky19 F1 expressed the most severe symptoms of 3.85 and 3.61 respectively at week
13 , although this was not significantly different from the others. The least symptom severity score (2.0) at week was found in cultivar Adom and Asutem which recorded mild symptoms throughout the study period.

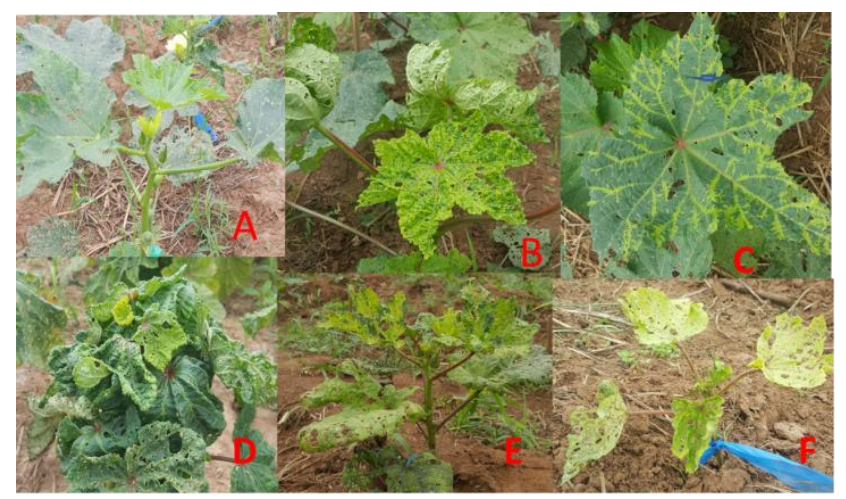

Figure-1. Viral disease symptoms found on the okra cultivars A: Healthy plant, B: mosaic, blistering and upward cupping of leaves, $C$ : vein clearing, D: leaf malformation, E: mosaic and F: leaf yellowing, upward cupping of leaves and stunting.

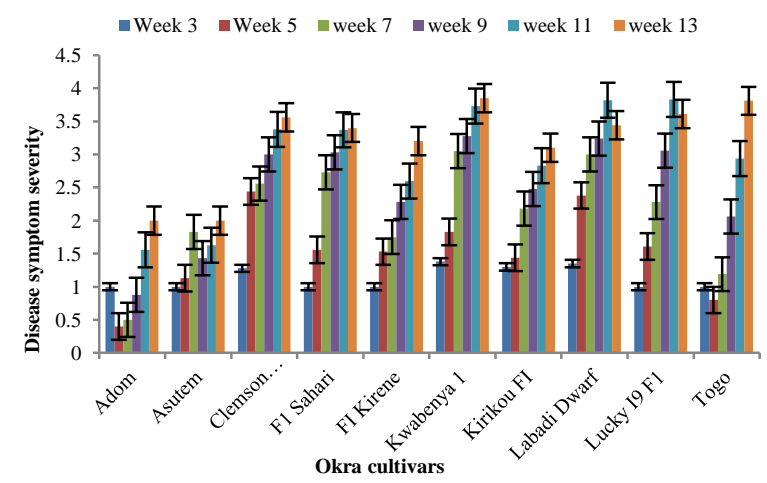

Figure-2. Index of symptom severity for diseased plants of 10 okra cultivars. Bars represent the standard error of means of four replications.

\section{Influence of OkMV on plant height at initial flowering stage \\ OkMV infection influenced plant height at initial flowering stage. Generally, plant height was significantly $(\mathrm{P}<0.05)$ reduced in diseased plants of all cultivars. The reduction in plant height was most severe in cultivars CS (38\%), F1K (35\%), AD (35\%) and F1S $(24 \%)$ (Fig. 3). The overall percentage reduction in plant height of diseased plants compared to healthy plants was $19.7 \%$.}


Plant height at $50 \%$ flowering stage was significantly as affected by OkMV infection

Plant height at 50\% flowering was significantly $(\mathrm{P}<0.05)$ influenced by the effects of infection of OkMV (Fig. 4). In all cultivars, at 50\% flowering, plant height was significantly $(\mathrm{P}<0.05)$ reduced in diseased plants. The reduction in plant height was more pronounced in cultivars $\mathrm{AD}(24 \%), \mathrm{CS}(35 \%), \mathrm{F} 1 \mathrm{~K}$ $(28 \%)$ and F1S $(26 \%)$ whilst KF1 had the lowest percentage reduction in plant height $(13 \%)$. The overall percentage reduction in plant height of diseased plants compared to the healthy ones was $20.4 \%$.



Figure-3. Effect of OkMV infection on plant height at initial flowering stage. Bars represent the standard error of means of four replications.

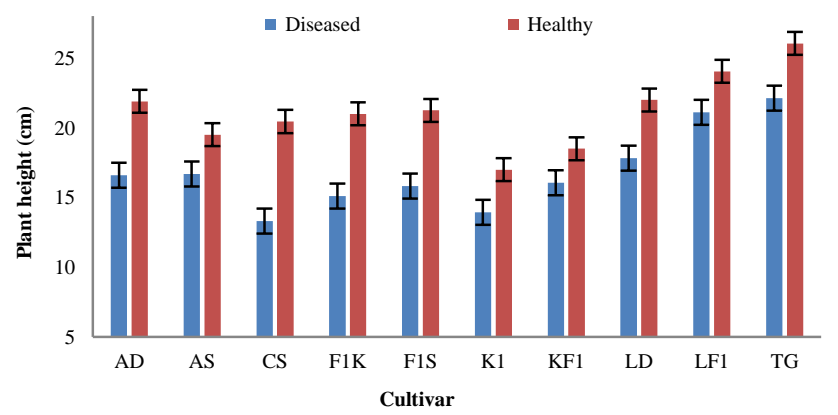

Figure-4. Effect of infection of OkMV on plant height at $50 \%$ flowering stage. Bars represent the standard error of means of four replications.

Plant height at 50\% podding stage was significantly as influenced by infection of OkMV

The effect of OkMV infection on plant height showed significant $(\mathrm{P}<0.05)$ differences when healthy and diseased plants were compared at $50 \%$ podding (Fig. 5). Plant height reduction was more pronounced in the cultivar CS (40\%) and least in KF1 (20\%). The overall percentage decrease in height of diseased plants was $14.9 \%$.
Days to $50 \%$ flowering as influenced by OkMV infection

Generally, diseased plants took significantly longer time to start flowering irrespective of the cultivar (Fig. 6). Diseased plants of cultivar K1, LD and AS took averagely the highest number of days (43 days) to attain $50 \%$ flowering. A second group comprising F1K, TG, F1S, CS, AD, KF1 and LF1 attained 50\% flowering earlier at an average number of 38 days. On the other hand, healthy plants of cultivars TG, F1S, F1K and AS took significantly the least number of days (25 days) to $50 \%$ flowering compared to the diseased ones.

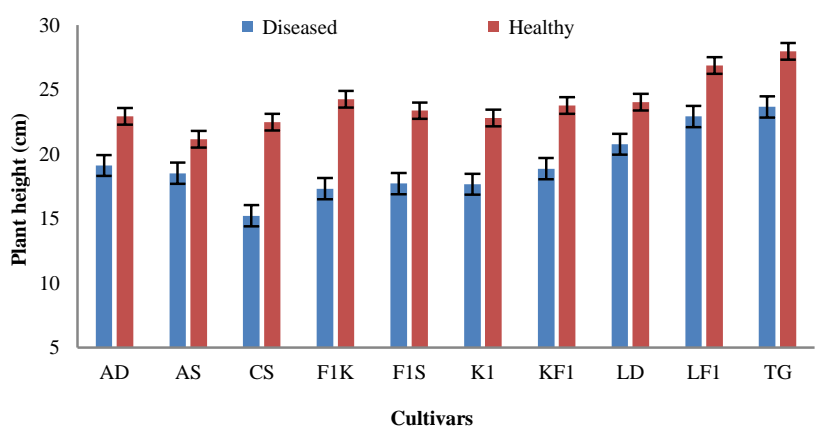

Figure-5. Effect of infection of OkMV on plant height at $50 \%$ podding stage. Bars represent the standard error of means of four replications.



Figure-6. Effects of infection of OkMV on days to $50 \%$ flowering. Bars represent the standard error of means of four replications.

Days to $50 \%$ podding as influenced by by OkMV Infection

Days to $50 \%$ podding was delayed by the viral infection in all the okra cultivars. Infected plants had significantly $(\mathrm{P}<0.05)$ delayed (average 47 days after planting) number of days to $50 \%$ podding compared to healthy plants with an average 35 days (Fig. 7). 
Infected plants of cultivars K1 and LD took the highest number of days of at least 51 days to attain $50 \%$ podding while cultivar $\mathrm{F} 1 \mathrm{~K}$ attained $50 \%$ podding significantly earlier at 35 days. Healthy plants of F1K, AS, LF1 and TG attained $50 \%$ podding earlier at average of 30 days after planting. However, when infected, attainment of $50 \%$ podding was delayed for about 16 days except $\mathrm{F} 1 \mathrm{~K}$ which attained $50 \%$ podding at 36 days even when diseased.

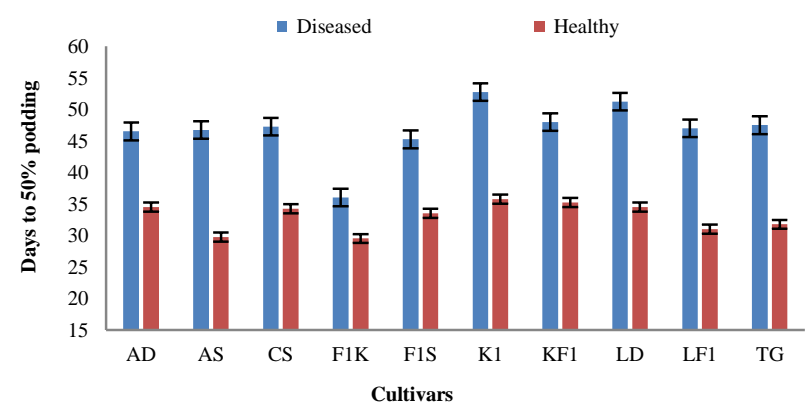

Figure-7. Effects of infection of OkMV on days to $50 \%$ podding. Bars represent standard error of four replications

Chlorophyll content as affected by infection of OkMV infection

Significantly $(\mathrm{P}<0.05)$ higher chlorophyll content was recorded in healthy plants of cultivar Clemson spineless (one of the most affected cultivars) than in diseased plants. Chlorophyll content of healthy plants increased from the third week after planting to the ninth week while that of the diseased plants decreased (Fig. 8).

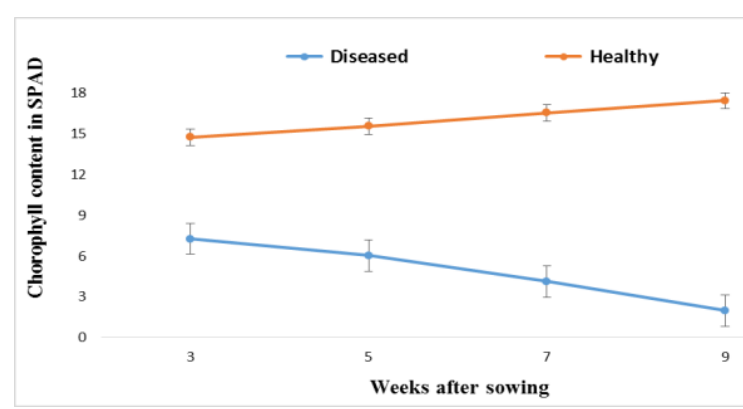

Figure-8. Effects of OkMV infection on the chlorophyll content of diseased plants of cultivar Clemson spineless.

\section{Pod length as affected by OkMV infection}

In all cultivars, virus infection caused significant $(\mathrm{P}<0.05)$ reduction in pod length. However, the effect of the disease on pod length reduction was much pronounced in TG where the average pod length of healthy plants was $50 \%$ longer than pods of diseased plants. Similarly, in cultivars LF1, K1 and KF1, average pod length decrease of $45 \%, 30 \%$ and $25 \%$ respectively were estimated. Diseased plants of cultivar AS produced significantly, the shortest pod lengths. With respect to percentage reduction in pod length, accession LF1 had the highest (52.19\%) whereas F1S had the lowest (26.44\%) (Table1).

Table-1. Effects of infection of OkMV on pod length of okra

\begin{tabular}{|c|c|c|c|}
\hline Cultivar & Sample & $\begin{array}{l}\text { Pod length } \\
\text { (mm) }\end{array}$ & $\begin{array}{c}\% \\
\text { Reduction }\end{array}$ \\
\hline \multirow{2}{*}{$\mathrm{AD}$} & Diseased & $19.95 \pm 7.16^{\text {cdefg }}$ & \multirow{2}{*}{29.38} \\
\hline & Healthy & $28.25 \pm 6.31^{\mathrm{ab}}$ & \\
\hline \multirow{2}{*}{ AS } & Diseased & $8.42 \pm 1.9^{\mathrm{i}}$ & \multirow{2}{*}{34.82} \\
\hline & Healthy & $12.92 \pm 1.84^{\text {fgh }}$ & \\
\hline \multirow{2}{*}{ CS } & Diseased & $12.30 \pm 1.35^{\mathrm{fgh}}$ & \multirow{2}{*}{40.82} \\
\hline & Healthy & $20.70 \pm 2.19^{\text {bcde }}$ & \\
\hline \multirow{2}{*}{ F1K } & Diseased & $15.12 \pm 3.25^{\text {efgh }}$ & \multirow{2}{*}{38.90} \\
\hline & Healthy & $24.75 \pm 5.72^{\mathrm{abcd}}$ & \\
\hline \multirow{2}{*}{ F1S } & Diseased & $16.55 \pm 5.42^{\text {fgh }}$ & \multirow{2}{*}{26.44} \\
\hline & Healthy & $22.50 \pm 7.59$ abcde & \\
\hline \multirow{2}{*}{ K1 } & Diseased & $17.30 \pm 6.60^{\text {cdefgh }}$ & \multirow{2}{*}{42.92} \\
\hline & Healthy & $30.30 \pm 7.25^{\mathrm{a}}$ & \\
\hline \multirow{2}{*}{ KF1 } & Diseased & $15.95 \pm 7.24^{\text {defgh }}$ & \multirow{2}{*}{39.05} \\
\hline & Healthy & $26.17 \pm 10.88^{\mathrm{abc}}$ & \\
\hline \multirow{2}{*}{ LD } & Diseased & $12.57 \pm 1.51^{\text {fgh }}$ & \multirow{2}{*}{28.45} \\
\hline & Healthy & $17.57 \pm 1.58^{\text {cde }}$ & \\
\hline \multirow{2}{*}{ LF1 } & Diseased & $12.55 \pm 1.07^{\mathrm{fgh}}$ & \multirow{2}{*}{52.19} \\
\hline & Healthy & $26.25 \pm 6.77^{\mathrm{ab}}$ & \\
\hline \multirow{2}{*}{ TG } & Diseased & $10.82 \pm 1.23^{\mathrm{gh}}$ & \multirow{2}{*}{47.14} \\
\hline & Healthy & $20.47 \pm 7.83^{\text {bcdef }}$ & \\
\hline
\end{tabular}

Each value is a mean of four replicates, and values followed by the same superscript(s) are not significantly different ( $p>0.05)$ according to Tukey's pairwise comparison.

\section{Pod width as influenced by OkMV infection}

The effect of OkMV infection on pod width reduction was significant $(\mathrm{P}<0.05)$ (Table 2$)$. Generally, all cultivars, local and exotic, healthy plants produced pods with bigger widths than pods produced from diseased plants. Healthy plants from F1K and AD produced significantly the biggest pod widths. On the other hand, diseased plants from TG, AS and CS cultivars produced the least pod widths. Percentage reduction in pod length was observed to be most pronounced in KF1 (35.22\%) and least in AD (26.89) (Table 2). Diseased plants of cultivar $\mathrm{AD}$ and $\mathrm{K} 1$ 
produced significantly the highest pod widths of $9.65 \pm 1.17$ and $8.80 \pm 0.90$ respectively compared to diseased plants of other cultivars.

Table-2. Effect of OkMV on pod width of okra

\begin{tabular}{|c|c|c|c|}
\hline Cultivar & Sample & Pod width (mm) & $\begin{array}{c}\% \\
\text { Reduction } \\
\end{array}$ \\
\hline \multirow{2}{*}{$\mathrm{AD}$} & Diseased & $9.65 \pm 1.17^{\text {cdefgh }}$ & \multirow{2}{*}{26.89} \\
\hline & Healthy & $13.20 \pm 1.15^{\mathrm{ab}}$ & \\
\hline \multirow{2}{*}{ AS } & Diseased & $5.87 \pm 1.05^{\mathrm{i}}$ & \multirow{2}{*}{27.79} \\
\hline & Healthy & $8.13 \pm 0.84^{\mathrm{fgh}}$ & \\
\hline \multirow{2}{*}{ CS } & Diseased & $6.25 \pm 0.52^{\mathrm{i}}$ & \multirow{2}{*}{46.25} \\
\hline & Healthy & $11.63 \pm 1.25^{\mathrm{ab}}$ & \\
\hline \multirow{2}{*}{ F1K } & Diseased & $8.50 \pm 1.40^{\text {defghi }}$ & \multirow{2}{*}{39.59} \\
\hline & Healthy & $14.07 \pm 3.17^{\mathrm{a}}$ & \\
\hline \multirow{2}{*}{ F1S } & Diseased & $8.42 \pm 2.52^{\text {efghi }}$ & \multirow{2}{*}{28.15} \\
\hline & Healthy & $11.72 \pm 3.25^{\mathrm{abcd}}$ & \\
\hline \multirow{2}{*}{ K1 } & Diseased & $8.80 \pm 0.90^{\text {defghi }}$ & \multirow{2}{*}{30.15} \\
\hline & Healthy & $12.60 \pm 1.58^{\mathrm{abc}}$ & \\
\hline \multirow{2}{*}{ KF1 } & Diseased & $7.30 \pm 3.14^{\mathrm{hi}}$ & \multirow{2}{*}{35.22} \\
\hline & Healthy & $11.27 \pm 3.44$ abcdef & \\
\hline \multirow{2}{*}{ LD } & Diseased & $7.55 \pm 1.43^{\mathrm{ghi}}$ & \multirow{2}{*}{30.22} \\
\hline & Healthy & $10.82 \pm 1.30^{\text {abcdef }}$ & \\
\hline \multirow{2}{*}{ LF1 } & Diseased & $8.05 \pm 0.25^{\text {fghi }}$ & \multirow{2}{*}{36.11} \\
\hline & Healthy & $12.60 \pm 1.45^{\mathrm{abc}}$ & \\
\hline \multirow{2}{*}{ TG } & Diseased & $5.62 \pm 0.62^{\mathrm{i}}$ & \multirow[b]{2}{*}{46.22} \\
\hline & Healthy & $10.45 \pm 3.54^{\text {bcdefgh }}$ & \\
\hline
\end{tabular}

Each value is a mean of four replicates, and values followed by the same superscript(s) are not significantly different at $(\mathrm{p}>0.05)$ according to Tukey's pairwise comparison.

Fresh pod weight as affected by OkMV infection Fresh fruit weight was significantly $(\mathrm{P}<0.05)$ reduced by the effect of OkMV (Table 3). Generally, viral infection caused an estimated $50 \%$ reduction in the fresh fruit weights comparing healthy and diseased plants. Cultivar F1K was found to produce the heaviest fresh fruit weights while diseased plants of F1S, LD and AS produced significantly the lightest fresh fruit weights. Cultivars that produced intermediate fresh fruit weights from diseased plants include AD, CS, K1,
KF1, LF1 and TG. Highest percentage reduction in fresh fruit weight was seen in cultivar LF1 $(52.19 \%)$ whilst LD (28.45\%) had the lowest.

Table-3. Effects of infection of OkMV on fresh fruit weight of okra

\begin{tabular}{|c|c|c|c|}
\hline Cultivar & Sample & $\begin{array}{c}\text { Mean fresh } \\
\text { fruit weight (g) }\end{array}$ & $\begin{array}{c}\% \\
\text { Reduction } \\
\end{array}$ \\
\hline \multirow{2}{*}{$\mathrm{AD}$} & Diseased & $19.95 \pm 7.16^{\mathrm{fgh}}$ & \multirow{2}{*}{29.38} \\
\hline & Healthy & $28.25 \pm 6.31^{\mathrm{bc}}$ & \\
\hline \multirow{2}{*}{ AS } & Diseased & $8.42 \pm 1.93^{\text {gh }}$ & \multirow{2}{*}{34.83} \\
\hline & Healthy & $12.92 \pm 1.84^{\mathrm{def}}$ & \\
\hline \multirow{2}{*}{$\mathrm{CS}$} & Diseased & $12.30 \pm 1.35^{\mathrm{gh}}$ & \multirow{2}{*}{40.57} \\
\hline & Healthy & $20.70 \pm 2.19^{b}$ & \\
\hline \multirow{2}{*}{ F1K } & Diseased & $15.12 \pm 3.25^{\mathrm{cde}}$ & \multirow{2}{*}{38.90} \\
\hline & Healthy & $24.75 \pm 5.72^{\mathrm{a}}$ & \\
\hline \multirow{2}{*}{ F1S } & Diseased & $16.55 \pm 5.42^{\mathrm{h}}$ & \multirow{2}{*}{26.44} \\
\hline & Healthy & $22.50 \pm 7.59^{\mathrm{efg}}$ & \\
\hline \multirow{2}{*}{ K1 } & Diseased & $17.30 \pm 6.60^{\text {fgh }}$ & \multirow{2}{*}{42.90} \\
\hline & Healthy & $30.30 \pm 7.25^{b}$ & \\
\hline \multirow{2}{*}{ KF1 } & Diseased & $15.95 \pm 7.24^{\mathrm{gh}}$ & \multirow{2}{*}{39.05} \\
\hline & Healthy & $26.17 \pm 10.88^{\text {cde }}$ & \\
\hline \multirow{2}{*}{ LD } & Diseased & $12.57 \pm 1.51^{\mathrm{h}}$ & \multirow{2}{*}{28.45} \\
\hline & Healthy & $17.57 \pm 1.58^{\text {bcd }}$ & \\
\hline \multirow{2}{*}{ LF1 } & Diseased & $12.55 \pm 1.07^{\mathrm{gh}}$ & \multirow{2}{*}{52.19} \\
\hline & Healthy & $26.25 \pm 6.77^{\mathrm{bc}}$ & \\
\hline \multirow{2}{*}{ TG } & Diseased & $10.82 \pm 1.23^{\mathrm{gh}}$ & \multirow[b]{2}{*}{47.19} \\
\hline & Healthy & $20.47 \pm 7.83^{\mathrm{bcd}}$ & \\
\hline
\end{tabular}

Each value is a mean of four replicates, and values followed by the same superscript(s) are not significantly different $(p>0.05)$ according to Tukey's pairwise comparison.

\section{Correlation among four essential traits in ten okra cultivars}

Correlation coefficients were worked out to study the relationship of chlorophyll content (CC) with fresh fruit weight (FFW), pod width (PW) and pod length (PL). The results of correlation coefficients indicated that chlorophyll content shared very strong positive correlation with fresh fruit weight (FFW) and pod width (PW) but weak negative correlation with pod length. Fresh fruit weight (FFW) exhibited very weak 
correlation with pod length (PL) but very strong positive correlation with pod width (PW) while Pod length (PL) and pod width (PW) shared very strong positive correlation.

Table-4. Correlation among chlorophyll content, fresh fruit weight, pod length and pod width

\begin{tabular}{|c|c|c|c|c|}
\hline & CC & FFW & PL & PW \\
\hline FFW & $\mathbf{0 . 4 0 6 7}^{* *}$ & & & \\
\hline & $\underline{0.0002}$ & & & \\
\hline PL & $\mathbf{- 0 . 0 7 8 7}^{\text {ns }}$ & $\mathbf{- 0 . 0 2 2 3}^{\text {ns }}$ & & \\
\hline & $\underline{0.4936}$ & $\underline{0.8465}$ & & \\
\hline PW & $\mathbf{0 . 2 2 6 8}^{*}$ & $\mathbf{0 . 3 4 6 0}^{* *}$ & $\mathbf{0 . 7 8 6 2}^{* * *}$ & \\
\hline & $\underline{0.0458}$ & $\underline{0.0019}$ & $\underline{0.0000}$ & \\
\hline
\end{tabular}

$\mathrm{CC}=$ Chlorophyll content, FFW $=$ Fresh fruit weight, $\mathrm{PL}=$ Pod length, $\mathrm{PW}=$ Pod width

Below each correlation coefficient (bolded) is $\mathrm{P}$-value (underlined). *, **, *** represent significant correlation at $\mathrm{P} \leq 0.05,0.01,0.001$ respectively. $\mathrm{ns}=$ not significant at $\mathrm{P} \leq 0.05$.

\section{Discussion}

It is noteworthy that the ten okra cultivars assessed in this study were previously evaluated for Okra mosaic disease resistance in which all cultivars succumbed to the OkMV infection (Appiah et al., 2020). In the current study, symptom expression among the cultivars was severe, perhaps due to cultivar susceptibility, strain of the virus and probably the influence of other viruses which were not detected in this study. The infection resulted in different kinds of symptoms which culminated in poor plant growth. The reduction in plant growth and yield as a result of virus infection has been reported (Chen et al., 2019; Latham et al., 2004).

Generally, plant height at initial flowering stage, 50\% flowering and $50 \%$ podding stages was significantly reduced in diseased plants of all cultivars. The average percentage reduction in plant height of diseased plants compared to healthy plants at initial flowering stage was $19.7 \%$. This result corroborates the findings of Ndunguru and Rajabu (2004) who recorded 19.5\% reduction in plant height between virus-infected and healthy plants. In most of the cases, stunting was severe, probably due to mixed infections with other viruses. Cho et al. (2000), observed severe plant damage as a result of infection caused by two or more viruses. However, it must be noted that the disparity in the percentage reduction in plant height observed in the different cultivars in this study could be a result of the differences in genetic make-up of the cultivars resulting in differential reactions to the virus. Reduction in the height of virus-infected plants have been reported in groundnuts (Appiah et al., 2016), cowpea (Kareem and Taiwo, 2007) and pepper (Pazarlar et al., 2013).

Generally, flowering was delayed in diseased plants of all cultivars compared to healthy or control plants. Diseased plants took significantly longer time to flower irrespective of cultivar. Delay in flowering in tomato plants infected with Potato virus $X$ and Tobacco mosaic virus (Balogun, 2003) and okra plants infected with OkMV (Ndunguru and Rajabu 2004) has been reported (Ndunguru and Rajabu, 2004). The delayed flowering observed in diseased cultivars in this study could be due to impaired photosynthesis,

ineffective uptake of nutrients, and other stress conditions imposed by the disease during the growing period of the cultivars (Niser et al., 2002). As in days to $50 \%$ flowring podding was significantly affected by the viral infection in all the okra cultivars. The infection significantly delayed the number of days to $50 \%$ podding compared to healthy plants by an average of 35 days. Viruses have a remarkable impact on their host metabolism, with carbohydrate and chlorophyll metabolism being two activities which are seriously affected by viral infections. Chlorophyll content decreased in virus-infected plants of all the cultivars. Lower levels of chlorophyll observed in the virusinfected plants in this study may be due to inefficient functioning of chlorophyllase, leading to poor development of chloroplast or inhibition of chlorophyll synthesis as reported by Zhao et al., 2016 and Roca and Minguez-Mosquera (2003). Furthermore, the chlorotic and mosaic symptoms observed on the virus-infected plants could indicate the occurrence of chloroplastvirus interactions (Zhao et al., 2016; Rahoutei et al., 2001), resulting in fluctuation of chlorophyll fluorescence and reduced chlorophyll pigmentation (Liu et al., 2014). The reduction in the chlorophyll content may have resulted in reduced photosynthetic activity culminating in low yields. Parimala et al. (2009) reported a decrease in yield of virus-infected okra as a result of reduced chlorophyll content. In this study, chlorophyll content showed a strong positive correlation with fresh fruit weight. There has been a growing interest on the part of plant breeders to develop higher yielding varieties of crops (Nestel et al., 2006; Gregorio, 2002). Therefore, information on the association between the chlorophyll content and yield 
parameters will serve as a useful guide in future breeding efforts. Results from the correlation analysis implies that targeting high chlorophyll content of okra leaves through breeding will consequently lead to improvement in fresh fruit weight and pod width.

Significant reduction in pod length, width and weight was observed in virus-infected plants of all the cultivars. Generally, for all cultivars; local or exotic, healthy or control plants produced pods with bigger widths than pods produced from diseased plants. It is noteworthy that despite the infection, diseased plants of cultivar $\mathrm{AD}$ and $\mathrm{K} 1$ produced significantly higher pod widths than diseased plants of other cultivars. This may suggest that these cultivars are tolerant to viral infections and therefore may offer some bases for their selection for introgression of desirable genes for high fruit yield into preferred cultivars. Tolerance of okra cultivars to OYVMV have been reported (Mohsan et al., 2017). OkMV infection reduced fresh fruit weight of all cultivars. The viral infection resulted in an estimated $50 \%$ reduction in the fresh fruit weights compared to weights recorded in healthy plants. The reduction in the fruit weight of the virus-infected okra cultivars observed in this study could be due to reduction in photosynthesis (Liu et al., 2014) resulting from the viral infection. Differences in the average fresh pod weight per plant observed among the cultivars may be attributed to inherent fruit characteristics such as higher pod diameter, higher number of pods per plant, fruit length, and higher number of branches per plant (Mahapatra et al., 2007; Mohammad et al, 2001 and Singh and Jain, 2002).

Pod length, pod width and fresh fruit weight are desirable characteristics for domestic, industrial and commercial preference (Alam and Hossain, 2008). Results from the current study indicate that pod length, pod width and fresh fruit weight were considerably decreased in diseased plants compared to records of these characters in the healthy or control plants. Furthermore, reports by Echezona and Offordile (2011) attributed the cause to the feeding activity of Podagrica spp. that causes damage to the leaves resulting in significant reduction in the photosynthetic capacity. Similar reduction in the yield of okra cultivars as a result of OkMV infection has been reported (Fajinmi and Fajinmi, 2010).

In addition to the effect of OkMV on growth and performance of the okra cultivars, the result of this study has also revealed significant variation among cultivars with respect to pod length, pod width and fresh fruit weight. This implies a broad range of genetic variability which could be exploited in breeding programmes. Singh et al. (2017), observed significant variation among okra cultivars, suggesting variations that are useful for studying genetic diversity of okra germplasm. Cultivars K1, AD and F1K are the best with respect to pod length, pod width and fresh fruit weight and therefore can be selected as parents in future breeding work.

\section{Conclusion}

This study has elucidated the effect of okra mosaic disease on the growth and performance of ten okra cultivars under field conditions within the coastal savannah agro-ecological zone of Ghana. All ten okra cultivars succumbed to the disease but had varying levels of reduction in growth and performance. Diseased plants compared to healthy ones had significantly reduced $(\mathrm{p} \leq 0.05)$ chlorophyll content, plant height, delayed flowering process and fresh pod weight. Lower levels of chlorophyll content were observed in the virus-infected plants with consequent reduction in photosynthetic activity culminating in lower yields. Plant height of diseased plants was significantly reduced compared to healthy or control plants at initial flowering stage. The viral infection also significantly delayed the achievement of $50 \%$ podding by an average of 35 days. Similarly, fresh fruit weights of diseased plants decreased by an estimated $50 \%$ compared to weights recorded in healthy plants. The observed significant reduction in the yield parameters caused by OkMV disease emphasises the damaging potential of the disease on okra cultivation and the need for improved control measures to maximise production. Two local cultivars, Adom and Asutem were found to be the best performing cultivars under field conditions having recorded less reduction in fresh fruit weight despite the infection. Therefore, these cultivars can be selected as locally-adapted, good materials tolerant to OkMV for further improvement in future breeding work.

\section{Acknowledgement}

We wish to profoundly commend the invaluable contributions of Mr. Yusif Mohammed as well as staff of the Biotechnology Centre that have enabled the success of this work. We also acknowledge the Biotechnology and Nuclear Agriculture Research Institute (BNARI) of the Ghana Atomic Energy Commission (GAEC) for permitting the use of the 
Molecular Biology Laboratory and other facilities to carry out this study.

Disclaimer: None.

Conflict of Interest: None.

Source of Funding: None.

\section{References}

Aguero J, Gomez-Aix C, Sempere RN, Garcia-Villalba R, Garcia-Nunez J, Hernando Y and Aranda MA, 2018. Stable and broad spectrum cross-protection against Pepino Mosaic Virus attained by mixed infection. Front. Plant Sci. 9: 1810. doi https://doi.org/10.3389/fpls.2018.01810.

Ahiakpa, J. K. Magdy, M., Werner. O., Amoatey, H. M., Yeboah, M. A., Appiah A. S., Quartey, E. K, Ros, R. M. (2017). Intra-specific variation in West African and Asiangermplasm of okra (Abelmoschus spp. L.). Annals of Agricultural Science 62:131- 138.

Akaho EKH, Maakuu BT, Anim-Sampong S, EmiReynolds G, Boadu HO, Osae EK, Akoto-Bamford S, Dodoo-Amoo DNA, 2003. Intermediate safety analysis report (GAEC-

NNRI- RT-90).

Alam A and Hossain MM, 2008. Variability of different growth contributing parameters of some okra (Abelmoschus esculentus L.) accessions and their interrelation effects on yield. J. Agric. Rural Devel. 6: 25-35.

Appiah AS, Amiteye S, Boateng F and Amoatey HM, 2020. Evaluation of okra (Abelmoschus esculentus L. Moench) cultivars for resistance to Okra mosaic virus and Okra yellow vein mosaic virus. Australas. Plant Pathol. 49(11): DOI:10.1007/s13313-020-00727-3

Appiah AS, Offei SK, Tegg RS and Wilson CR, 2016. Varietal response to groundnut rosette disease and the first report of Groundnut ringspot virus in Ghana. Plant Dis. 100: 946-952.

Asare-Bediako E, Addo-Quaye A and Bi-Kusi A, 2014. Comparative efficacy of plant extracts in managing whitefly (Bemisia tabaci Gen) and leaf curl disease in okra (Abelmoschus esculentus

L). Am. J. Agric. Sci. Technol. 2(1): 31-41.

Adetuyi FO, Osagie AU and Adekunle AT, 2011. Nutrient, anti-nutrient, mineral and zinc bioavailability of okra Abelmoschus esculentus (L) Moench Variety. Am. J. Food Nutr. 1(2): 49-54.

Balogun OS, 2003. Patterns of disease manifestation in tomato seedlings singly or doubly infected with Potato $\mathrm{X}$ potexvirus and Tobacco mosaic tobamovirus. Biokemistri 14: 64-74.

Chen S, Wellin L and Guohui Z, 2019. Symptoms and yield loss caused by rice stripe mosaic virus. Virol. J. 16(145). DOI: https://doi.org/10.1186/s12985019-1240-7

Cho JD, Kim JS, Choi HS, La YJ and Kim KS, 2000. Ultrastructural aspects of the mix infections of watermelon mosaic potyvirus isolated from pumpkin and cucumber green mottle mosaic tobamovirus from watermelon. Plant Pathol. 16: 216-221.

Dickson KB and Benneh G, 2004. A new geography of Ghana. Longmans Group Limited, London, UK.

Echezona BL and Offordile JI, 2011. Responses of flea beetles (Podagrica spp.) and okra plants (Abelmoschus esculentus L. Moench) to differently coloured polyethylene shades. Int. J. Pest Manage. 57(2): 161-168.

Fajinmi AA and Fajinmi OB, 2010. Incidence of okra mosaic virus at different growth stages of okra plants ([Abelmoschus esculentus (L.)] Moench) under tropical condition. J. Gen. Mol. Virol. 2(1): 28-31.

Gregorio GB, 2002. Progress in plant breeding for trace minerals in staple crops. J Nutr. 132: $500-$ 502.

Hull R, 2002. Matthew's plant Virology 4th edition. Academic Press, San Diego, California, USA.

Kareem KT and Taiwo MA, 2007. Interactions of viruses in Cowpea: effects on growth and yield parameters. Virol. J. 4: 15. DOI:10.1186/1743422X-4-15

Kumar N, Barua S, Riyesh T, Chaubey KK, Rawat KD, Khandelwal N, Mishra AK, Sharma N, Chandel SS, Sharma S, Singh MK, Sharma DK, Singh SV and Tripathi BN, 2016. Complexities in isolation and purification of multiple viruses from mixed viral infections: viral interference, persistence and exclusion. PLoS One 11: $\mathrm{e} 0156110$.

Latham LJ, Jones RAC and Coutts BA, 2004. Yield losses caused by virus infection in four combinations of non-persistently aphidtransmitted virus and cool-season crop legume. Austr. J. Exp. Agric. 44(1). Ea03060.

Liu J, Yang J, Bi H and Zhang P, 2014. Why mosaic? Gene expression profiling of African cassava mosaic virus-infected cassava reveals the effect of 
chlorophyll degradation on symptom development. J. Integr. Plant Biol. 56: 122-132.

Mahapatra MR, Acharyya P and Sengupta S, 2007. Variability and association analysis in okra. Indian Agric. 51: 17-26.

Mohammad A, Muhammad SM and Mushtaq Y, 2001. Comparative study on the performance of some exotic okra. Int. J. Agric. Biol. 3: 423-425.

Mohsan M, Saeed S and Qamar S, 2017. Varietal reaction of different okra cultivars against Okra yellow vein mosaic virus under field condition. Adv. Res. J. Multidisc. Discov. 10(4): 18-21.

Ndunguru J and Rajabu AC, 2004. Effect of okra mosaic virus disease on the above-ground morphological yield components of okra in Tanzania. Sci. Hortic. 99: 225-235.

Nestel P, Bouis HE, Meenakshi JV and Pfeiffer W, 2006. Biofortification of staple food crops. J.

Nutr. 136: 1064-1067.

Niser N, Irfan M, Khan J, Nabi G, Muhammed I and Badshah N, 2002. Influence of various levels of nitrogen and phosphorus on the growth and yield of Chilli. Asian J. Plant

Sci. 1(5): 599-601.

Oppong-Sekyere D, Akromah R, Nyamah EY, Brenya $\mathrm{E}$ and Yeboah S, 2012. Evaluation of some okra (Abelmoschus spp L.) germplasm in Ghana. Afr. J. Plant Sci. 6(5): 166-178.

Parimala P, Prabhu IM and Muthuchelian K, 2009. Physiological response of yellow vein mosaic virus-infected bhendi [Abelmoschus esculentus] leaves. Physiol. Mol. Plant Pathol. 74: 129-133.

Pazarlar S, Gumus M and Oztekin GB, 2013. The Effects of Tobacco mosaic virus Infection on Growth and Physiological Parameters in Some Pepper Varieties (Capsicum annuum L.) Notulae Botanicae Horti Agrobotanici Cluj-Napoca, 41(2), 427-433. https://doi.org/10.15835/nbha4129008

Petlamul W, Ngampongsai A and Petcharat J, 2009. Oviposition preference of papaya fruit fly, Bactrocera papayae Drewand Hancock (Diptera: Tephritidae) on some chili varieties. Thaksin
Univ. J. 12: 43-49.

Prakasha TL, Patil MS and Benagi VI, 2010. Survey for bhendi yellow vein mosaic disease in parts of Karnataka. Karnataka J. Agric. Sci. 23: 658-659.

Rahoutei J, García-Luque I and Barón M, 2001. Inhibition of photosynthesis by viral infection: effect on PSII structure and function. Physiol. Plant. 110: 286-292. 10.1034/j.13993054.2000.110220.

Roca M and Minguez-Mosquera MI, 2003. Involvement of chlorophyllase in chlorophyll metabolism in olive varieties with high and low chlorophyll content. Physiol. Plant. 117: 459-66.

Savary S, Ficke A, Aubertot J-N and Hollier C, 2012. Crop losses due to diseases and their implications for global food production lossess and food security. Food Security. 4(4): DOI: 10.1007/s12571-012-0200-5

Singh DK and Jain SK, 2002. Performance of okra cultivars. Annual Research Report. Submitted to DES. Pantnager. pp. 3-5.

Singh N, Singh DK, Sati UC, Rawat M and Pandey P, 2017. Genetic analysis studies in okra [Abelmoschus esculentus (L.) Moench]. Int. J. Pure Appl. Biosci. 5: 361-367.

Zhao J, Zhang X, Hong Y and Liu Y, 2016. Chloroplast in plant-virus interaction. Front. Microbiol. 7: 1565.

\section{Contribution of Authors}

Amiteye S, Appiah AS and Boateng F:

Contributed to the conceptualization of the study, experimental design, data analysis and interpretation, article review and final approval of manuscript.

Kutufam JT: Contributed to research design, data collection and final reading of the manuscript.

Amoatey HM: Contributed to the conceptualization of the study, manuscript critiquing and final approval of the manuscript. 